\title{
Knowledge, Awareness and Practice of Road Traffic Safety Among the Dental Students
}

\author{
S.Vignesh ${ }^{1}$ and Dhanraj Ganapathy ${ }^{2}$ \\ ${ }^{1}$ Saveetha Dental College and Hospitals, Saveetha Institute of \\ Medical and Technical Science,Saveetha University, Chennai, India. \\ ${ }^{2}$ Professor and Head, Department of Prosthodontics, Saveetha Dental College and Hospitals, \\ Saveetha Institute of Medical and Technical Science, Saveetha University, Chennai, India.
}

\begin{abstract}
To evaluate the knowledge and awareness about road traffic safety among dental students. Road safety is important for all road users. Every year more than one million people are injured in road accidents in India. In recent years, the number of vehicles on roads has increased, as has the number of goods transported by road. This makes road safety even more important. Road safety awareness is one of the most important aspects towards safety concerning traffic rules among adolescent children. Adolescent age groups are rapidly emerging as a major population of vehicle owners and may derive a thrill out of taking risks on road without realizing the consequences This is mainly a cross-sectional type of study, in which standardized structured questionnaires were prepared and given to dental students of various colleges. The sample size was about 250 and the duration study was 1 month. The knowledge and awareness about the road traffic safety among dental students was found to be quite satisfactory. The awareness about road traffic safety among the dental students was satisfactory, and more awareness can be given through posters, seminars and mass media.
\end{abstract}

KEY WORDS: ROAD ACCIDENTS, DENTAL STUDENTS, ROAD VEHICLES..

\section{INTRODUCTION}

Road accidents are undesired events that lead to injury or death. These deaths and injuries result in significant social and economic costs. Occupational fatalities occur in road traffic and transportation crashes (Kulkarni et al., 2013;Ravichandran, Priya and Gayathri, 2019;Ranasinghe, Gayathri and Vishnu Priya, 2018;Raj et al., 2011). In addition to professional drivers, other

\section{ARTICLE INFORMATION}

*Corresponding Author: dhanraj@saveetha.com

Received 15th June 2020 Accepted after revision 7th August 2020

Print ISSN: 0974-6455 Online ISSN: 2321-4007 CODEN: BBRCBA

Thomson Reuters ISI Web of Science Clarivate Analytics USA and Crossref Indexed Journal

\section{Clarivate}

NAAS Journal Score 2020 (4.31) SJIF: 2020 (7.728)

A Society of Science and Nature Publication,

Bhopal India 2020. All rights reserved.

Online Contents Available at: http//www.bbrc.in/

Doi: http://dx.doi.org/10.21786/bbrc/13.7/55 workers, for whom driving is not their core activity, are also frequently required to travel by road, e.g. all commuting workers also use the road. Young people, between 15 and 24 years old, face the largest risk in traffic: they make up 11\% of the Population but 17\% of all road fatalities. Pedestrians, cyclists, moped riders and motorcyclists have a higher injury rate per kilometre of travel than other road users. Work-related accidents on the road may involve any traffic type. Human error is often seen as the cause of road accidents(Kulkarni et al., 2013;AlZahrani, 2015;Redhwan and Karim, 2010; India, 2017). While it may not be possible to stop people from making mistakes, these mistakes need not result in fatalities. The traffic environment must be developed in such a way that human errors do not lead to serious consequences.

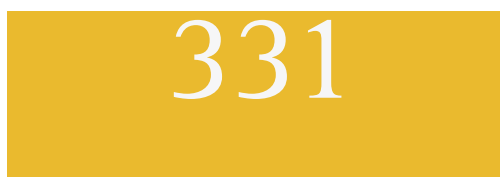


Road safety means safety for all road users. Accident risks on the road, during both work-related driving and leisure time driving, involve risks to the driver, passengers and other road users. Today's continuously changing traffic environment requires constant alertness on the part of road users. Speeding, drunk driving and failure to wear a seat belt are the three main reasons for road accidents (Swami et al., 2006; Mathy, Saveetha College of Nursing and Thenmozhi, 2016). Traffic regulations are intended to decrease the risk of accidents. Improving road safety involves dealing with issues related to road users, the traffic environment, and the condition of vehicles. Investigating road accidents can also prevent further accidents. Work-related road safety should be managed by integrating it into the arrangements for managing overall health and safety at work. Work-related road safety should be managed by integrating it into the employers' arrangements for managing overall health and safety at work. Work-related traffic accidents can be prevented through technical measures and organisational measures at workplaces, and adequate training. In addition, investigating road accidents can prevent future accidents(Kulothungan, 2015;Khanjani, Tavakkoli and Bazargan-Hejazi, 2019).

Road traffic death rates in low and middle income countries are more than double in comparison with high income countries. Worldwide, India has the worst road traffic accident rate, where everyday about 1,374 accidents and 400 deaths take place, which have earned a dubious distinction with over 1,30,000 deaths annually(Khanjani, Tavakkoli and Bazargan-Hejazi, 2019). Previously our department has published extensive research on various aspects of prosthetic dentistry ('Evaluation of Corrosive Behavior of Four Nickel-chromium Alloys in Artificial Saliva by Cyclic Polarization Test:An in vitro Study', 2017; Ganapathy, Kannan and Venugopalan, 2017; Jain, 2017a, 2017b; Ranganathan, Ganapathy and Jain, 2017; Ariga et al., 2018; Gupta, Ariga and Deogade, 2018; Anbu et al., 2019; Ashok and Ganapathy, 2019; Duraisamy et al., 2019; Varghese, Ramesh and Veeraiyan, 2019), this vast research experience has inspired us to research about knowledge, awareness and practice of road traffic safety among the dental students. Hence, the present study aimed to assess the awareness and practice of road traffic safety rules among dental college students in Chennai, Tamil Nadu so that a better overview of the situation can be made.

\section{MATERIAL AND METHODS}

This was a quantitative non-experimental study with cross-sectional survey design conducted in the month of December 2019 among dental college students of Chennai, District of Tamil Nadu. The sample size of this particular study is about 250 students. The students were mainly above the age group of 21 years A predesigned questionnaire was used for the data collection and it mainly has two sections. Section A: Demographic variables of the students which includes their name, age, gender, year of study, residential area, socio-economic status, type of vehicle users. Section B: Structured knowledge related 20 questions were framed and each question was graded with the score of (1) for each correct answer and the score of (0) for each wrong answer, such as they were classified according to the three categories as poor awareness ( (0-5) score, average awareness (6-15) score and good awareness (16-20) score.

The data were Collected from the self- structured administered questions. The collected data were tabulated and analysed in accordance with objectives of the study by using descriptive and inferential statistics with the help of Statistical Package for the Social Sciences version 16 software.

\section{RESULTS AND DISCUSSION}

The results from the present study were analysed.

\begin{tabular}{|c|c|c|c|}
\hline S.No & $\begin{array}{l}\text { Socio- } \\
\text { economic } \\
\text { variables }\end{array}$ & Frequency & Percentage \\
\hline \multirow[t]{5}{*}{1.} & Age & & \\
\hline & 19 years & 10 & $4 \%$ \\
\hline & 20 years & 15 & $6 \%$ \\
\hline & 21 years & 158 & $63 \%$ \\
\hline & 22 years & 67 & $28 \%$ \\
\hline 2. & Gender & & \\
\hline \multirow[t]{5}{*}{3.} & $\begin{array}{c}\text { Male } \\
\text { Female } \\
\text { Year of Study }\end{array}$ & $\begin{array}{l}148 \\
102\end{array}$ & $\begin{array}{l}59 \% \\
41 \%\end{array}$ \\
\hline & Third year & 10 & $4 \%$ \\
\hline & Final year & 165 & $66 \%$ \\
\hline & Interns & 48 & $19 \%$ \\
\hline & PG & 27 & $11 \%$ \\
\hline \multirow[t]{3}{*}{4.} & Residential area & & \\
\hline & Urban area & 238 & $95 \%$ \\
\hline & Rural area & 12 & $5 \%$ \\
\hline \multirow[t]{3}{*}{5.} & Vehicle used most & & \\
\hline & Two wheeler & 170 & $68 \%$ \\
\hline & Four wheeler & 80 & $32 \%$ \\
\hline \multirow[t]{4}{*}{6.} & Socio-economic status & & \\
\hline & High class & 100 & $40 \%$ \\
\hline & Middle class & 138 & $55 \%$ \\
\hline & Low class & 12 & $5 \%$ \\
\hline
\end{tabular}

Section 1: Demographic detail about the dental college students: The analysis of the demographic variables of the dental college students were presented [Table 1]. The most of the students participated were above the age group of 21 years (63\%). There were more final year students participating in the survey (66\%). Majority of the students (59\%) were male who participated in the study. The residential area of all the students were mostly urban areas (95\%). Most of the students (55\%) were from the middle class type of family. Among the 
students participated in the study most of them were 2 wheeler users (68\%).

Section 2: Description level of awareness and practice about road traffic safety among the dental students: The study findings of awareness regarding road safety rules among dental college students revealed that 5(2\%) had had poor awareness, 167(66.8\%) had average awareness and $78(31.2 \%)$ had good awareness. The mean and standard deviation of the awareness score regarding road safety rules was $23.6 \pm 3.46$. The item wise awareness regarding road safety rules were depicted [Table 2]. The study findings of practice regarding road safety rules among dental college students revealed that 10(4\%) had had unsatisfactory practice, 195(78\%) had partially satisfactory practice and 45(18\%) had satisfactory practice. The mean and standard deviation of the practice score regarding road safety rules was $5.86 \pm 0.96$. The item wise practise regarding road safety rules were depicted [Table 3]

Table 2. Table showing the distribution of description level of awareness and practice about road traffic safety among the dental students.

\begin{tabular}{|l|c|c|c|c|}
\hline S.No & Questionnaire & $\begin{array}{c}\text { Number } \\
\text { with correct } \\
\text { response }\end{array}$ & Percentage \% & $\begin{array}{c}\text { Correct } \\
\text { answer }\end{array}$ \\
\hline 1. & $\begin{array}{c}\text { Eligible age to get } \\
\text { a driving license }\end{array}$ & 222 & $89 \%$ & 18 years \\
\hline 2. & $\begin{array}{c}\text { Average speed limit for } \\
\text { driving in Tamil Nadu }\end{array}$ & 165 & $66 \%$ & 50 -60 Kph \\
\hline 3. & $\begin{array}{c}\text { Safety limit of blood alcohol } \\
\text { concentration for driving (BAC) }\end{array}$ & 190 & $76 \%$ & 20-30 mg of \\
alcohol/100ml
\end{tabular}

Road safety awareness is one of the most important aspects towards safety concerning traffic rules among adolescent children. Adolescent age group is rapidly emerging as a major population of vehicle owners and may derive a thrill out of taking risks on road without realizing the consequences, hence it is very important to assess awareness and practice on road safety rules and sensitise this population as they are future of the nation (Kalbandkeri, G. and Ghooli, 2018;Tripathi et al., 2014).

The findings of the present study showed that the majority of final year dental students i.e. $68.8 \%$ had average awareness and only $31.2 \%$ had good awareness. This finding is similar to the study conducted among college students in Indore, Chandigarh and Guntur city. $65.3 \%$ of the students were aware about the traffic rules.This finding is consistent with findings of the study conducted among medical students in Barabanki, UttarPradesh. 56.7\% of the students were aware about the rules for pedestrians (Ratna et al., 2017;Peden, 2008;Zador, Krawchuk and Voas, 2000). This finding is contradictory to study conducted among medical students in Barabanki, Uttar Pradesh where the awareness was high.

About $89 \%$ of the students knew the legal age for the driving license. This finding is similar with the studies conducted in Indore, Chandigarh, Guntur city, whereas it is high as compared to the study conducted among the medical students in Barabanki, UttarPradesh. 72\% of the students were aware about the right way of overtaking. This finding is similar to the study conducted among college students in Indore and Chandigarh (R., Vijaylaxmi and Dorle, 2017).

Almost half of the students were able to identify the given traffic sign correctly Similar findings were observed in the study conducted among college students in Guntur city and rural area of Tamil Nadu (Mukhopadhyay et al., 2017). This awareness was much higher than the study conducted among the various College students in Indore, Guntur city and Barabanki, UttarPradesh (Zaidi et al., 2017).

The findings of the present study showed that there was a significant positive correlation $(p=0.001)$ between awareness and practice of road safety rules. This finding is consistent with the findings of a study conducted among students in Barabanki, UttarPradesh(Zaidi et al., 2017). The present study on the awareness of the dental students revealed the relationship between the age, year of study, type of vehicle usage and the socio-economic status. 


\begin{tabular}{|c|c|c|c|}
\hline S.No & Questions & Response & Percentage $\%$ \\
\hline \multirow[t]{3}{*}{1.} & $\begin{array}{l}\text { Do you think following traffic } \\
\text { rules and regulations will } \\
\text { reduce accidents }\end{array}$ & & \\
\hline & Yes & 218 & $87 \%$ \\
\hline & No & 32 & $13 \%$ \\
\hline \multirow[t]{2}{*}{2.} & $\begin{array}{c}\text { Do pedestrians must be given } \\
\text { importance regarding their security. } \\
\text { Yes }\end{array}$ & 198 & $79 \%$ \\
\hline & No & 52 & $21 \%$ \\
\hline \multirow[t]{3}{*}{3.} & $\begin{array}{l}\text { Is it necessary to have a driving } \\
\text { license while driving a vehicle }\end{array}$ & & \\
\hline & Yes & 215 & $86 \%$ \\
\hline & No & 35 & $14 \%$ \\
\hline \multirow[t]{3}{*}{4.} & $\begin{array}{l}\text { Does road signs and symbols helps } \\
\text { in reducing road accidents }\end{array}$ & & \\
\hline & Yes & 205 & $82 \%$ \\
\hline & No & 45 & $18 \%$ \\
\hline \multirow[t]{2}{*}{5.} & $\begin{array}{l}\text { Do you wear the necessary safety } \\
\text { protective equipment while driving }\end{array}$ & & \\
\hline & Yes & 210 & $84 \%$ \\
\hline \multirow[t]{5}{*}{6.} & $\begin{array}{l}\text { No } \\
\text { What are the main reasons which } \\
\text { make you speed up while driving ? }\end{array}$ & 40 & $16 \%$ \\
\hline & Stress & 80 & $32 \%$ \\
\hline & Thrilling experiences & 43 & $17 \%$ \\
\hline & Morning attendance & 90 & $36 \%$ \\
\hline & Delay in your daily routine & 37 & $15 \%$ \\
\hline
\end{tabular}

\section{CONCLUSION}

The majority of dental students had good awareness and partial satisfactory practice; so there is a need to sensitise this population. Efforts should be made in improving the awareness about road safety through posters, seminars and mass media. Strict enforcement of laws and periodic organization of traffic awareness campaigns and practice relating to road safety should be encouraged to reduce the morbidity and mortality related to road traffic accidents. Essential self-interest for safety measures to be present to control the road accidents.

\section{ACKNOWLEDGEMENTS}

The authors of this study would like to express their gratitude towards everyone who facilitated and enabled us to carry out this study successfully. We would also thank the institute for helping us to have access to all the case records for collecting the required cases for conducting this study.

Conflict of Interest: There were no conflicts on interest as declared by the authors

\section{REFERENCES}

AlZahrani, A. (2015) 'Knowledge and attitude toward road traffic regulations among students of Health Sciences College in Taif Region, KSA', International Journal of Medical Science and Public Health, p. 241. doi: 10.5455/ijmsph.2015.2810201447.

Anbu, R. T. et al. (2019) 'Comparison of the Efficacy of Three Different Bone Regeneration Materials: An Animal Study', European journal of dentistry, 13(1), pp. 22-28.

Ariga, P. et al. (2018) 'Determination of Correlation of Width of Maxillary Anterior Teeth using Extraoral and Intraoral Factors in Indian Population: A Systematic Review', World Journal of Dentistry, 9(1), pp. 68-75.

Ashok, V. and Ganapathy, D. (2019) 'A geometrical method to classify face forms', Journal of oral biology and craniofacial research, 9(3), pp. 232-235.

Duraisamy, R. et al. (2019) 'Compatibility of Nonoriginal Abutments With Implants: Evaluation of Microgap at the Implant-Abutment Interface, With Original and Nonoriginal Abutments', Implant dentistry, 28(3), pp. 
289-295.

Evaluation of Corrosive Behavior of Four Nickelchromium Alloys in Artificial Saliva by Cyclic Polarization Test:An in vitro Study' (2017) World Journal of Dentistry, 8(6), pp. 477-482.

Ganapathy, D. M., Kannan, A. and Venugopalan, S. (2017) 'Effect of Coated Surfaces influencing Screw Loosening in Implants: A Systematic Review and Meta-analysis', World Journal of Dentistry, 8(6), pp. 496-502.

Gupta, P., Ariga, P. and Deogade, S. C. (2018) 'Effect of Monopoly-coating Agent on the Surface Roughness of a Tissue Conditioner Subjected to Cleansing and Disinfection: A Contact Profilometric Study', Contemporary clinical dentistry, 9(Suppl 1), pp. S122S126.

India, S. Y. B. (2017) 'Transport Research Wing, Ministry of Surface Transport. Ministry of Statistics \& Programme Implementation'.

Jain, A. R. (2017a) 'Clinical and Functional Outcomes of Implant Prostheses in Fibula Free Flaps', World Journal of Dentistry, 8(3), pp. 171-176.

Jain, A. R. (2017b) 'Prevalence of Partial Edentulousness and Treatment needs in Rural Population of South India', World Journal of Dentistry, 8(3), pp. 213-217. Kalbandkeri, L. R., G., B. and Ghooli, S. (2018) 'A study to assess the knowledge and practice of road safety measures among undergraduate medical students of M. R. Medical College, Kalaburagi', International Journal of Community Medicine And Public Health, p. 1596. doi: 10.18203/2394-6040. ijcmph20181241.

Khanjani, N., Tavakkoli, L. and Bazargan-Hejazi, S. (2019) 'Factors related to cell phone use while driving based on the Theory of Planned Behavior among university students in Kerman, Iran', Journal of injury Ct violence research, 11(2), pp. 203-212.

Kulkarni, V. et al. (2013) 'Awareness and practice of road safety measures among undergraduate medical students in a South Indian state', Journal of Forensic and Legal Medicine, pp. 226-229. doi: 10.1016/j. jflm.2012.09.022.

Kulothungan, K. (2015) 'A cross sectional study on the knowledge, awareness and practice of safety rules among the young college students in Trichy City, Tamilnadu', Journal of government information: an international review of policy, issues and resources. researchgate.net, 2(9), pp. 1162-1169.

Mathy, I., Saveetha College of Nursing and Thenmozhi, P. (2016) 'Assess the Knowledge and Practice On Road Safety Regulations among Primary School Children in
Rural Community', International Journal of Medical Science, pp. 1-5. doi: 10.14445/23939117/ijmsv3i8p101.

Mukhopadhyay, D. J. et al. (2017) 'Road Safety Awareness among College Students in a North Indian Town', Journal of medical science and clinical research. doi: 10.18535/jmscr/v5i9.170.

Peden, M. (2008) World Report on Road Traffic Injury Prevention: Summary. DIANE Publishing.

Raj, C. K. P. et al. (2011) 'Study of knowledge and behavioural patterns with regard to road safety among high school children in a rural community in Tamil Nadu, India', Indian Journal of Medical Specialities. doi: 10.7713/ijms.2011.0028.

Ranasinghe, A. N., Gayathri, R. and Vishnu Priya, V. (2018) 'Awareness of effects of sleep deprivation among college students', Drug Invention Today. search.ebscohost.com, 10(9). Available at: https://bit. ly/30hicdL

Ranganathan, H., Ganapathy, D. M. and Jain, A. R. (2017) 'Cervical and Incisal Marginal Discrepancy in Ceramic Laminate Veneering Materials: A SEM Analysis', Contemporary clinical dentistry, 8(2), pp. 272-278.

Ratna, H. V. K. et al. (2017) 'Awareness and behaviour patterns regarding road safety measures among undergraduate students', International Journal of Community Medicine And Public Health, p. 944. doi: 10.18203/2394-6040.ijcmph20170947.

Ravichandran, S., Priya, V. V. and Gayathri, R. (2019) 'Awareness on road safety among college students', Drug Invention Today. search.ebscohost.com, 12(7). Available at: https://bit.ly/3eGPQyC

Redhwan, A. A. and Karim, A. J. (2010) 'Knowledge, Attitude and Practice Towards Road Traffic Regulations Among University Students, Malaysia', IIUM Medical Journal Malaysia. journals.iium.edu.my, 9(2). Available at: https://journals.iium.edu.my/kom/index.php/imjm/ article/view/716 (Accessed: 1 July 2020).

R., M., Vijaylaxmi, B. H. and Dorle, A. S. (2017) 'A study on knowledge and practice of road safety among medical students of S.N. Medical College, Karnataka', International Journal of Community Medicine And Public Health, p. 1993. doi: 10.18203/2394-6040. ijcmph20172163.

Swami, H. M. et al. (2006) 'Road safety awareness and practices among school children of Chandigarh', Indian journal of community medicine: official publication of Indian Association of Preventive \& Social Medicine. medind.nic.in, 31, p. 199.

Tripathi, M. et al. (2014) 'Profile of patients with head 
injury among vehicular accidents: an experience from a tertiary care centre of India', Neurology India. neurologyindia.com, 62(6), pp. 610-617.

Varghese, S. S., Ramesh, A. and Veeraiyan, D. N. (2019) 'Blended Module-Based Teaching in Biostatistics and Research Methodology: A Retrospective Study with Postgraduate Dental Students', Journal of dental education, 83(4), pp. 445-450.

Zador, P. L., Krawchuk, S. A. and Voas, R. B. (2000)
'Alcohol-related relative risk of driver fatalities and driver involvement in fatal crashes in relation to driver age and gender: an update using 1996 data', Journal of Studies on Alcohol, pp. 387-395. doi: 10.15288/ jsa.2000.61.387.

Zaidi, S. et al. (2017) 'Risk perception and practice towards road traffic safety among medical students', International Journal of Community Medicine and Public Health. doi: 10.18203/2394-6040.ijcmph20164397. 